\title{
HOFSTEDE'S CULTURAL DIMENSIONS AND R\&D INTENSITY AS AN INNOVATION STRATEGY: A VIEW FROM DIFFERENT INSTITUTIONAL CONTEXTS
}

\author{
Isabel Gallego-Álvarez \\ Universidad de Salamanca \\ Instituto Multidisciplinar de Empresa (IME) \\ Departamento de Administración y Economía de la Empresa \\ Campus Miguel de Unamuno, Edificio FES \\ 37007-Salamanca \\ Spain \\ e-mail: igallego@usal.es

\section{María Consuelo Pucheta-Martínez \\ Universidad Jaume I} \\ Departamento de Finanzas y Contabilidad \\ Campus del Riu Sec, s/n \\ 12071-Castellón \\ Spain \\ Phone: 0034964387141 \\ e-mail: pucheta@uji.es
}

Corresponding author: María Consuelo Pucheta-Martínez

\section{ACKNOWLEDGEMENTS}

The authors acknowledge financial support from the Spanish Ministry of Economy, Industry and Competitiveness for the research project ECO 2017-82259-R and from the University Jaume I, Spain, for the research project UJI-B2018-15. 


\title{
HOFSTEDE'S CULTURAL DIMENSIONS AND R\&D INTENSITY AS AN INNOVATION STRATEGY: A VIEW FROM DIFFERENT INSTITUTIONAL CONTEXTS
}

\begin{abstract}
The impact of all six of Hofstede's cultural dimensions (power distance, individualism/collectivism, masculinity/femininity, uncertainty avoidance, long-term/short-term orientation, and restraint/indulgence) on business innovation practice has not, to the best of our knowledge, been hitherto examined. Past research has focused on four or five of these cultural dimensions. The aim of this study is therefore to analyse how corporate innovation policies are affected by all these dimensions in a sample of firms operating in different countries. The paper draws on institutional theory, whereby firms domiciled in the same institutional context will behave in a similar manner and their decisions on innovation practices will therefore also be similar. The findings show that the cultural dimensions of power distance, masculinity, uncertainty avoidance, and long-term orientation are positively associated with innovation, while individualism has a negative effect, and indulgence has no effect whatsoever.
\end{abstract}

Keywords: Cultural dimensions, cultural contexts, innovation, institutional theory.

JEL Code: DO2, M14, O3, 


\section{HOFSTEDE'S CULTURAL DIMENSIONS AND R\&D INTENSITY AS AN INNOVATION STRATEGY: A VIEW FROM DIFFERENT INSTITUTIONAL CONTEXTS}

\section{Introduction}

Innovation is today considered of considerable importance for firms, as levels of competition are swiftly rising and production methods are rapidly improving. Organisations need to have new ideas that lead to new products, processes and programmes, and to develop new technologies that improve their performance and competitiveness and lead to products that set them apart from their competitors. According to Brem et al. (2016) and Naqshbandi (2016), innovation is considered extremely important in ensuring sustainable economic development and competitive advantage. Culture has been acknowledged as one of the factors that have an impact on innovation: as a major component of international management and organisational development, it has a significant contribution to make in corporate and economic advancement (Rohlfer and Zhang, 2016). Organisations interact with their environment, and cultural values affect the way companies do so.

One of the first studies to analyse the impact of the cultural context on innovation was conducted by Shane (1993), who examined that relationship in a number of countries using the framework propounded by Hofstede. Kaasa and Vadi (2010) subsequently focused on companies in Europe. Furthermore, authors including Smale (2016,) contend that culture should be taken into account in most studies on innovation, as innovative activities involve cooperation between a number of organisations and the sharing of resources in a society, although not all cultural dimensions have the same impact on innovation across all countries.

Institutional theory underpins this research, as it permits a comparative study to be made of the effect of culture on innovation in companies. This approach assumes that corporations are part of a nexus of formal and informal institutions, including culture, which have a direct impact on their operations. We therefore turn to institutional theory to systematically delineate the effects of such cultures on the innovative activities undertaken (DiMaggio and Powell, 1983; Scott, 2001).

In view of the above, this study aims to provide further evidence of the impact that different cultures have on corporate innovation, from the perspective of institutional theory. To do so, it follows the cultural dimensions proposed by Hofstede (1983), Hofstede and Hofstede (2005), and Hofstede, Hofstede, and Minkov (2010), defined as power distance, individualism/collectivism, masculinity/femininity, uncertainty avoidance, long-term/short-term orientation, and restraint/indulgence. In general, the main findings of this research are that certain cultural dimensions, such as power distance, masculinity, uncertainty avoidance and long-term orientation, have a positive impact on corporate innovation. In contrast, other variables, such as individualism, negatively affect innovation, while indulgence has no impact.

This study thus contributes to the field by extending existing knowledge on how national cultures affect innovation by considering a sample of 28 countries, complementing previous studies that have focused on a single country or specific geographical regions, such as European countries. A 
further contribution lies in the inclusion of all the dimensions proposed by Hofstede, compared to previous studies, which have considered only four or five (e.g. indulgence has hardly ever been used). A third contribution is deduced from the results, as not all dimensions have the same impact on organisational innovation: some dimensions have a positive effect, while others have a negative one or no impact at all. In short, it is important that companies analyse cultural factors when deciding on innovation policies.

The paper is developed in the following sections: the theoretical framework relative to national culture and innovation is described in the next section. Section 3 formulates the hypotheses proposed in this research, while Section 4 describes the methodology and the variables used. Section 5 presents an analysis of the results and, finally, Section 6 covers the conclusion of the research and the implications of its findings.

\section{National culture and innovation}

According to institutional theory, organisations are influenced by cultural aspects (Scott, 2008), whereby culture plays an important role in performance, as organisations are not detached from their environment, but instead interact with it through their employees, customers and suppliers. This means that the cultural norms that surround an organisation have a profound impact on the values and behaviour promoted within it, as it adapts to society's beliefs, values and norms, rendering it socially acceptable and enabling it to obtain the necessary resources and legitimacy to ensure its performance and survival.

It is therefore important to define the meaning of culture, and how it affects corporate decisions in matters of innovation. According to Vitell et al. (2003), culture may be defined as a collective programming of the mind, which is wholly invisible and unconscious and difficult to change, shaping the core values not only of people but also of companies. Along these same lines, Parboteeah and Cullen (2003, p. 138) consider that culture is a historically determined set of implicit and explicit abstract beliefs and notions, constituting what is good, correct and desirable, which are shared by a group of individuals who have experienced a common background. These cultural values, norms, beliefs and assumptions are symbolically reinforced and conveyed through socialisation and passed on from one generation to the next. For scholars such as Su (2006) and Tsakumis (2007), national culture has a major impact on the ethics of decision-making processes and is expected to influence organisational structure, management behaviour and business operations (Richardson and Boyd, 2005). Nevertheless, business innovation differs from most corporate policies in that innovative results are highly uncertain and depend on a company's human capital and, therefore, on the company's preferences and other values (Chen et al., 2017).

Innovation has been defined as the generation of new ideas through a multistage process, in which companies turn ideas into products or new processes (Baregheh et al., 2009). Rujirawanich et al. (2011) also refer to the significance of innovation in enabling companies to identify new ideas that 
are converted into new products, services, technologies or programmes, with the aim of strengthening the organisation's performance and growth, keeping it sustainable and achieving organisational success. Innovation, therefore, enables companies to create new technology or improve their existing resources, a crucial ability in today's business world (Mohnen and Hall, 2013). Indeed, major decisions are made in companies by taking into account issues of innovation (Lorca and de Andrés, 2019), and Conner (1991) considers that innovation is of the utmost significance in helping companies to be strategically competitive and to produce valuable products, differentiated from those of their competitors.

A number of studies have analysed the impact of cultural context on innovation. Shane (1993) was one of the first academics to analyse the relationship between cultural dimensions and innovation in different countries, using the framework proposed by Hofstede, and found that uncertainty avoidance has the greatest impact on innovation. Kaasa and Vadi (2010) also analysed that relationship in companies within European countries and concluded that individualism is positively related to innovation. According to Smale (2016), culture should always be addressed in studies on innovation, as it defines the interaction between the individuals and organisations involved in innovation activities, by considering collaboration, the sharing of resources, creativity, and the entrepreneurial spirit in a given society. Nevertheless, not all cultural dimensions exert the same influence on innovation in all countries. Thus, for example, in Asian countries including Japan, South Korea or China, collectivism is the dimension with the greatest influence, yet these are also among the world's most innovative countries. The aforementioned scholars also consider that in Eastern European countries insufficient research has been conducted into how culture influences innovation. In this regard, Kaasa and Vadi (2010) posit that it may be important to analyse different combinations of cultural dimensions, rather than just the relationship between specific dimensions and innovation. In view of the above, this research seeks to analyse how corporate innovation responds to different cultural systems.

Considering 41 countries, Chen et al. (2017) analyse how cultural norms in the dimensions of individualism-collectivism and uncertainty avoidance affect corporate innovation (the measure of innovative output is the number of patent applications, subsequently granted, made by each firm in each year). The results show that firms located in countries with higher levels of individualism generate more and higher impact patents, and are more efficient in converting R\&D into innovative output. In contrast, firms located in countries with higher levels of uncertainty avoidance produce fewer and less significant patents and are less efficient with their R\&D expenditure. Taken together, the findings report that national culture plays an important role in influencing corporate innovation around the world. Similar evidence was provided by Efrat (2014), who supports the notion that cultural aspects, specifically individualism, masculinity and uncertainty avoidance, still motivate innovation. Two measures were used to capture innovation, each referring to a different aspect: patents and high-technology exports. Previously, Shane (1993) used per capita number of trademarks as a 
measure of innovation. He finds that individualism and uncertainty avoidance have the highest impact on national innovation rates.

Examining other determinants of R\&D intensity, such as cumulative knowledge, Davenport and Prusak (2000) highlight the importance of national culture in the knowledge transfer process within a cross- culture business context. In this regard, Chen et al (2010) and Magnier- Watanabe and Senoo (2010) indicate that cumulative knowledge can be promoted in societies where the individual's interests are above those of the group; the dissemination of knowledge can be promoted in maledominated societies, where decisive and aggressive management is preferred over intuition and consensus; and societies that avoid high levels of uncertainty, where risk tolerance and uncertainty are low, can support the application of knowledge.

In the case of intellectual property (IP) protection, various investigations such as that carried out by Budde-Sung (2013), explore how cultural dimensions impact on IP protection. Individualism, in particular, seems to be a cultural dimension associated with IP protection. Uncertainty avoidance implies a greater application of rules and laws (Wollan et al. 2009), which society values positively, as this improves high-tech industries and reduces ambiguity by enacting strict IP protection laws. There is, therefore, also a close relationship between uncertainty avoidance and IP protection. In addition, future orientation or long-term orientation may also predict a greater level of IP protection, due to the existence of strong IP protection laws, whose objective is to allow inventors to receive benefits from their inventions for sufficient time to recover the cost incurred in research and development as well as allowing an economic return for a certain period.

\section{Research hypotheses}

The impact of a particular culture is most commonly analysed through the dimensions proposed by Hofstede (1980, 2001), Hofstede and Hofstede (2005), and Hofstede et al. (2010). Although the model initially included four cultural dimensions (power distance, uncertainty avoidance, individualism, and masculinity), two more were subsequently added (long-term orientation and indulgence), comprising the current six cultural dimensions. These dimensions provide a major theoretical framework, not only for analysing a national culture but also for considering the effects that cultural differences have on innovation. According to Hoecklin (1996), this theoretical framework is particularly useful in understanding people's view of an organisation, the mechanisms that are deemed appropriate for controlling and coordinating its operations, and its members' roles and relationships. However, this cultural model has some limitations, one of which is that Hofstede's model explains patterns that are observable when the agents are whole nations, not individuals (Minkov, 2018). Smith et al. (2002) argue that some cultural aspects are not equivalent in all countries; for instance, the employees of Japan's government may not be comparable with those of Western countries because government employees do not have the same status in all countries. Additionally, Baskerville (2003) suggests that some of Hofstede's cultural dimensions are more oriented to socio-economic issues than 
cultural. In line with this view, Jones (2007) agrees that 'four or five dimensions do not give sufficient information about cultural differences. Hofstede agrees. He believes that additional dimensions should continue to be added to his original work'. In fact, two new cultural dimensions were added to the four originally considered by Hofstede: long-term orientation and indulgence.

However, despite the criticisms and limitations, Hofstede's model has been used for many years, making a very significant contribution to studies of organisational cultures, and his scholarship remains part of mainstream theory in international business research and management studies (Kirkman et al., 2006).

Hofstede's working framework was developed using a sample of IBM employees, collecting data from their answers to questions on their values and their opinions on their conditions of employment. Some of these questions related to personal time, physical conditions, job security, freedom, cooperation, use of skills and training. They can be elaborated, according to Hofstede (1980), as: Do you have sufficient time left for your personal or family life? Do you have good physical conditions such as adequate work space, good ventilation, etc.? Do you have job security? Do you have enough freedom to adopt your own approach to the job? Do you have training opportunities to improve your skills and your knowledge, or to learn new skills and knowledge? Overall, Hofstede (1980) gathered the answers from 32 statements on values provided by 117,000 IBM employees in 40 countries. He observed approximately 90 significant and independent correlations of variables or indicators with his first four dimensions to further validate his results. Hofstede (1983) subsequently replicated and extended his study to include a total of 50 countries, finding the same dimensions. Later investigations provide the scores on these dimensions in 76 countries, partly based on replications and extensions of the IBM study on different international populations and by different scholars (Hofstede et al., 2010). The fact is that Hofstede's cultural model (Hofstede, 2001; Hofstede and Hofstede, 2005; Hofstede et al., 2010) has been widely used in academic research in varied fields including accountancy, administration, economics and sociology (Vollero et al., 2020; Rattrie et al., 2020; WeiHan, 2019). In this study, this cultural model is applied to innovation, a field that has been less frequently analysed in previous studies.

As regards innovation measures, the academic literature has considered $R \& D$ to be the first step in innovation and technological progress (Lerner and Wulf, 2007; Nekhili and Gatfaoui, 2013), because it is the initial stage in technological innovation that involves obtaining new knowledge applicable to the company's commercial requirements, which will eventually lead to new or improved products, processes, systems or services that can increase the company's sales and earnings. In addition to this, other measures have been used to measure innovation: Dedahanov et al. (2016) consider new and innovative ideas; Allred and Swan (2004) and Chen et al. (2017) believe that innovation should be measured by R\&D intensity; new product development is the measure proposed by Yang and Li (2011); design and new technology is suggested by Griffith and Rubera (2014) and 
Shane (1993) proposes the number of patents per capita or the number of trademarks registered per capita.

Considering the above, research hypotheses are now formulated for each one of Hofstede's cultural dimensions with a view to analysing innovation behaviour in different cultural contexts.

\subsection{Power distance}

Power distance is a dimension introduced by Hofstede (2001) to describe a society's hierarchy. It represents the extent to which the members of institutions and organisations within a given culture expect and accept power to be unevenly distributed. This inequality may be reflected in each individual's contribution to society and what they receive back in return, in terms of distribution of power and each person's rights and obligations. Scholars including Waldman et al. (2006) contend that cultures with a greater power distance accept that the hierarchy between managers and reports is broad and legitimate. Along the same lines, Miska et al. (2018) posit that people in cultures with high power-distance values tend to separate themselves into classes according to various criteria. Power bases tend to be stable, and power is considered to afford social order, relational harmony and stability.

On the relationship between power distance and innovation, Vecchi and Brennan (2009) report that power distance has a positive impact on innovation, as companies in countries with a greater power distance invest considerably more in $R \& D$ than their counterparts in countries with a lesser power distance. The reason for this may be that companies in these cultural environments find it easier to overcome the barriers to innovating in new products and to introduce the changes required for installing their production processes (Ambos and Schlegelmilch, 2008). Zhang and Zhou (2015) have found that power distance has a positive influence on innovation within the context of Chinese companies. To analyse this relationship, the following working hypothesis is proposed:

\section{H1: The greater the power distance in a society, the better its innovation processes.}

\subsection{Individualism}

In societies which value the individual, people feel comfortable having the individual authority to make a decision based on what they think is best. Individual freedom and independence are considered extremely important, and personal interests are prioritised over those of the social group. According to Bradley et al. (2013), an individualistic culture is more likely to see people making decisions independently to promote their own goals or achievements. It is therefore assumed that an individualistic culture nurtures risk-taking and reward in business operations. Hofstede (2001) stresses that the employees of organisations in countries with an individualistic culture have more freedom to develop or try out new products than do their peers in a collectivist culture. Furthermore, patents are known to be granted more often in individualistic cultures than in collectivist ones, and 
studies including that conducted by Lynn and Gelb (1996) have revealed a positive relationship between individualism and innovation.

Other studies have also shown that societies with a high level of individualism tend to record higher rates of growth and innovation, arguing that the greater freedom an individual has to explore and express opinions, the greater the likelihood is of new ideas emerging (Allred and Swan, 2004). According to Erez and Nouri (2010), individuals are quick to come up with new and creative ideas and to promote innovation (Desmarchelier and Fang, 2016). In earlier studies, Shane (1993) reported a positive relationship between patents and national levels of innovation and individualism; likewise, Jones and Teegen (2001) reported a positive correlation between foreign investment in $R \& D$ and individualism. Based on these arguments, we propose the following hypothesis:

H2: The greater the level of individualism in a society, the better its innovation processes.

\subsection{Masculinity/Femininity}

The dimension of masculinity/femininity refers to views of gender and the role of men/women in society. Male-dominated cultures tend to be assertive and focus on material success, while femaledominated ones tend to be more modest and focus on quality of life. Those societies considered masculine describe men as assertive, aggressive, ambitious, competitive and materialistic. At the same time, cooperative behaviour is valued less in this kind of society

According to Orij (2010), masculinity runs contrary to a culture's social orientation, and Peng et al. (2014) report that cultures with a high level of masculinity place greater importance on values such as professional career and business success. The relationship between masculinity and innovation seems to be positive for, as Efrat (2014) contends, people in a masculine society are self-assured, positive and ready to tackle challenges, with a strong sense of initiative and assertiveness, rendering them more likely to take a more innovative approach. Therefore, the higher a culture's level of masculinity, the higher the level of innovation in new products (Rhyne et al., 2002). In the same vein, Jones and Davis (2000) report that masculinity is related to incremental innovations, and therefore to R\&D efforts.

Considering the above, we formulate the following working hypothesis:

H3: The greater the level of masculinity in a society, the better its innovation process.

\subsection{Uncertainty avoidance}

According to Sully de Luque and Javidan (2004, p. 602), uncertainty avoidance is 'the extent to which ambiguous situations are threatening to individuals, to which rules and order are preferred, and to which uncertainty is tolerated in a society'. Societies with high levels of uncertainty avoidance impose more rules and regulations on people and are less favourably predisposed to change and innovation (De Mooij and Hofstede, 2010). Hofstede (2001) indicates that people in cultures with high uncertainty avoidance feel more anxious and, therefore, tend to adopt immediate steps to reduce the level of ambiguity. 
Innovation projects tend to have a high degree of uncertainty, with a consequent high likelihood of failure, and they require long-term horizons, so it is probable that companies located in countries with high levels of uncertainty avoidance will be less innovative than those operating in countries with low levels (Chen et al., 2017). According to Gaspay et al. (2008), cultures with high levels of uncertainty avoidance are risk-averse, which hinders the emergence of new ideas and the implementation of innovative practices. By contrast, companies in countries with low levels of uncertainty avoidance are more likely to promote innovative practices (Waarts and Van Everdingen, 2005). The same view is shared by Tian et al. (2018), who contend that, as uncertainty avoidance increases, the positive impact that technological innovation has on a company's market share tends to weaken, which means that low uncertainty avoidance benefits innovation. Taking into account these previous arguments, the next hypothesis is formulated as follows:

H4: The greater the uncertainty avoidance in a society, the worse the innovation process.

\subsection{Long-term orientation}

This dimension suggests that a society places considerable importance on future events. Furthermore, individuals belonging to societies of this kind believe that truth depends much more on the situation, context and time, and they have a strong propensity to save and invest, being known for their guile and perseverance (Hofstede et al., 2010). In turn, Van Everdingen and Waarts (2003) consider that cultures with a long-term focus are characterised by values such as persistence, the adjustment of traditions to new circumstances, personal adaptability, and the sense that the most important events in life will take place in the future. Therefore, companies in cultures with a long-term orientation will focus more on future outcomes and will be more receptive to changes than companies that operate in a culture with a short-term orientation.

Given that most technological developments require long-term planning and investment, the characteristics normally associated with the dimension of long-term orientation should correspond to higher levels of innovation (Jones and Davis, 2000). Rhyne et al. (2002) and Rujirawanich et al. (2011) report that long-term orientation is positively related to business innovations. The following hypothesis is therefore formulated:

H5: The greater the long-term orientation in a society, the better its innovation process.

\subsection{Indulgence}

This is the last dimension within Hofstede's cultural framework (Hofstede et al., 2010), and is related to the gratification of basic human desires related to the enjoyment of life. Indulgent societies are more permissive in relation to natural human desires regarding life's pleasures and having fun; they tend to have a greater appreciation of leisure, value freedom of speech highly, and a large percentage of their populations state that they are very happy. In this sense, as Ismail and Lu (2014, p.45) observe, 'people in indulgence societies prefer happiness and tend to create a perception of freedom, health, and control over life. Its opposite pole, restraint culture, refers to a society which controls the gratification of the abovementioned desires and feelings'. 
There are as yet few studies on the relationship between indulgence and innovation. Griffith and Rubera (2014) analyse how indulgence impacts on the relationship between technology and innovation in terms of market share. Their findings point to innovation's positive effect on market share, which increases along with a greater culture of indulgence. In the same vein, Syed and Malik (2014) found, in studying companies in Pakistan and USA, that cultures with high levels of indulgence tend to adopt new technologies more readily than countries with low levels, and argue that indulgent societies may encourage innovation as a way of continuously satisfying people's impulses related to fun and the enjoyment of life.

In light of the previous arguments, we propose the following working hypothesis:

H6: The greater the indulgence in a society, the better the innovation process.

\section{Empirical design}

\subsection{Sample and data}

Our initial sample was composed of 13,178 international firm-year observations from 2004 to 2015. However, 1,027 firm-year observations were excluded from the sample due to outliers and unavailable data for some variables. Thus, the final unbalanced panel data sample is composed of 12,151 firm-year observations, with a total of 1,560 companies in the final sample. Data for all the variables have been collected from the Thomson Reuters database, which encompasses companies from different countries and activity sectors. This database includes all countries in the targeted global indices (FTSE All World, Dow Jones Global, MSCI World, MSCI EMF, S\&P Global, S\&P/Citigroup) and is the premier source of detailed financial statement data and profile data on international companies. Financial entities were not included in the sample because they comply with different accounting rules from industrial companies, which make their financial statements incomparable.

A total of 28 countries are represented in the sample: Australia, Austria, Belgium, Brazil, Canada, Chile, China, Denmark, Finland, France, Germany, Greece, Hong Kong, India, Ireland, Italy, Japan, Mexico, Netherlands, New Zealand, Norway, Portugal, Spain, Sweden, Switzerland, Thailand, United Kingdom and United States. Table 1 shows that $28.19 \%$ of the sample's firms are domiciled in the United States, $14.21 \%$ in Japan, 9.21\% in the United Kingdom, 9.10\% in Canada and $6.49 \%$ in Australia. In contrast, the countries with the lowest representation are Greece with $0.05 \%$, Portugal with $0.24 \%$, Austria with $0.34 \%$ and New Zealand with $0.41 \%$.

\section{[Insert Table 1]}

Table 2 shows the nine sectors or industries in which the companies in the sample operate and the number of firms in each sector. This research is focused on the Thomson Reuters Business Classification (TRBC) economic sector classification by Thomson Reuters. The sectors with the greatest representation are industrials, consumer cyclical and basic metals with $21.58 \%, 19.19 \%$ and $14.11 \%$, respectively, while the lowest representation comes from telecommunications services with $3.35 \%$ and utilities with $6.0 \%$. 
[Insert Table 2]

\subsection{Dependent variable}

The dependent variable for measuring innovation in this study is Research and Development intensity (R\&D intensity), labelled as RD_INTENSITY, and calculated as the ratio between Research and Development expenses and total sales. Increases in R\&D intensity will imply that company strategy focuses on innovation, while decreases in $R \& D$ intensity will show a lesser interest in innovation. Our proxy for measuring R\&D intensity is one of the best-known from past research (Hoskisson et al., 1993; Archibugi and Planta, 1996; Allred and Swan, 2004; Nam et al., 2014). R\&D intensity helps a firm to develop new technical knowledge that can be integrated with current technologies, organisational processes, and products and services (Chaiporn and Olimpia, 2016). Lorca and de Andrés (2019) consider that $R \& D$ intensity represents the first phase in technological innovation that may result in new or improved new products, processes, systems or services to increase the company's sales and profits. However, some limitations can be also attributed to this proxy: it is considered an innovative input, showing the firm's efforts in innovation, but with no guarantee that these will be transformed into an innovative output. In this regard, Pellegrino and Piva (2019) explore how two innovative inputs (R\&D investments and technological acquisitions) are associated with two innovative outputs (product innovation and process innovation). These authors consider R\&D investment, which is similar to our proxy $R \& D$ intensity, as an innovative input. Kleinknecht et al. (2002) argue that another limitation of R\&D intensity is that it appears to focus on companies with manufacturing processes and tends to underestimate innovation in service companies. Therefore, it may have contributed to the fact that innovation is less developed in companies that belong to this sector of activity.

\subsection{Independent variables}

We have focused on the model of Hofstede (1980, 2001), subsequently improved by Hofstede et al. (2010), for measuring Hofstede's six cultural dimensions. This model of national cultural dimensions has been used by past research (Peng et al., 2014; Gallego-Álvarez and Ortas, 2017; Miska et al., 2018; Guptal et al., 2018) as a proxy for capturing the different cultures among countries. The six cultural dimensions are: (1) power distance, defined as POW_DIST; (2) individualism versus collectivism, defined as INDIV; (3) masculinity versus femininity, labelled as MASCUL; (4) uncertainty avoidance, labelled as UNC_AVOID; (5) long-term orientation, based on Confucian thinking, defined as LONG_ORIENTATION; and (6) indulgence versus restraint, labelled as INDULG. Scores for the six cultural dimensions range from 0 to 100 , with 50 being the halfway point. Countries with a score under 50 show a low cultural score for that dimension, while 50 or above is considered a high score. For instance, for the cultural dimension of short-term orientation versus longterm orientation, a score under 50 is categorised as shorter-term orientation, and above 50 as longerterm orientation. A country with a score of 30 would be designated as having a shorter-term orientation, but would have a lesser short-term orientation than another country with a score of 10 , 
because this figure is nearer 0 . All the values associated with each culture dimension are publicly available through the website of Geert Hofstede. ${ }^{1}$

\subsection{Control variables}

Some potential factors affecting innovation are controlled. Firstly, we control organisational size (e.g. Azar and Drogendijk, 2016), denoted as SIZE and calculated as the log of the total assets of firms; return on assets (Zhang, 2011), labelled as ROA, and calculated as operating income before interest and taxes over total assets; and the firm's leverage (Min and Smyth, 2016), denoted as LEVERAGE. Additionally, board size (Chouaibi et al., 2009) and board independence (Balsmeier et al., 2017) are controlled, labelled as B_SIZE and B_INDEP, respectively, and calculated as the number of directors on the board and the ratio between the total number of independent directors on the board and the total number of directors on the board. The governance of the country has been also considered, denoted as GOVERN (Sivak et. al., 2011), and calculated as an average of four components related to the country's governance, ranging from 0 to 10 (government consumption, transfers and subsidies, government enterprises and investment and top marginal tax rate); as well as the firm's liquidity (Zhang, 2011), labelled as LIQUIDITY, and measured as the ratio between total current assets and total current liabilities; and the gross domestic product of a country (e.g. Song et al., 2018), labelled as GDP, and calculated as the log of the gross domestic product of a country. The industry effects are also controlled (e.g. Azar and Drogendijk, 2016). We use the TRBC economic sector classification provided by Thomson Reuters. This variable is denoted as INDUSTRIES, and is calculated as a dummy variable that takes the value 1 if the firm operates in the industry considered and 0 , otherwise. We use the following nine sectors: basic materials, consumer cyclical, consumer non-cyclical, energy, healthcare, industrials, technology, telecommunication services and utilities. Finally, year effects $\left(\mathrm{YEAR}_{\mathrm{t}}\right)$ are also controlled by considering a set of dummy variables. Table 3 offers a description of all variables used in this paper.

\section{[Insert Table 3]}

\subsection{Model}

All hypothesis proposed will be checked with the following model:

$$
\begin{aligned}
& \text { RD_INTENSITY }_{\text {it }}=\quad \beta_{0}+\beta_{1} \text { POW_DIST }_{\text {it }} \quad+\beta_{2} \text { INDIV }_{\text {it }} \quad+\beta_{3} \text { MASCUL }_{\text {it }} \quad+\beta_{4} \text { UNC_AVOID }_{\text {it }} \\
& +\beta_{5} \text { LONG_ORIENTATION }_{\mathrm{it}}+\beta_{6} \text { INDULG }_{\mathrm{it}}+\beta_{7} \mathrm{SIZE}_{\mathrm{it}}+\beta_{8} \text { ROA }+\beta_{9} \text { LEVERAGE }_{\mathrm{it}} \\
& +\beta_{10} \text { B_SIZE } \mathrm{it}_{\mathrm{it}}+\beta_{11} \text { B_INDEP }{ }_{\mathrm{it}}+\beta_{12} \text { GOVERN }_{\mathrm{it}}+\beta_{12} \text { GOVERN }_{\mathrm{it}}+\beta_{13} \text { LIQUIDITY }_{\mathrm{it}}+ \\
& \beta_{14} \mathrm{GDP}_{\mathrm{it}}+\sum_{\mathrm{j}=15}{ }^{22} \beta \mathrm{jINDUSTRIES}{ }_{\mathrm{it}}+\sum \beta_{\mathrm{j}} \text { YEAR }_{\mathrm{t}}+\psi_{\mathrm{i}}+\mu_{\mathrm{it}}
\end{aligned}
$$

where $\psi_{\mathrm{i}}$ represents firm-specific or firm fixed effects (the unobservable heterogeneity), which are controlled because they might affect innovation. These firm-specific effects take into account unobservable organisational features, which do not change over time and change among individuals, and $\mu_{\mathrm{it}}$ represents the error term. 
This model has been run with the generalised method of moments (GMM) estimator (Arellano and Bond, 1991, 1998). With the GMM, in contrast to other estimators, the unobservable heterogeneity is controlled $\left(\psi_{\mathrm{i}}\right)$, which makes this procedure more consistent and efficient than others. The endogeneity is also addressed by the GMM procedure and, additionally, the estimation bias is alleviated.

The GMM procedure provides the following tests: the Wald $\chi^{2}$ test, the Arellano-Bond tests $\operatorname{AR}(1)$ and $\operatorname{AR}(2)$, and the Hansen test. The Wald $\chi^{2}$ statistic provides the model fitness. The existence of a second-order serial correlation in the first difference residuals is provided by the Arellano-Bond statistic $\mathrm{AR}(2)$. If the null hypothesis of 'no serial correlations' is rejected, then we can conclude that second-order serial correlation does not exist. Finally, the Hansen test of over-identifying restrictions shows the suitability of the instruments used in the model when the null hypothesis of non-correlation between the instruments and the error term is rejected.

\section{Analysis of results}

\subsection{Descriptive statistics and correlation}

Table 4 offers the descriptive statistics of all the variables used in this research. The variable R\&D intensity (RD_INTENSITY) is, on average, $2.21 \%$, showing that firms in our sample allocate $2.21 \%$ of their sales to Research and Development expenditure. Regarding the six cultural dimensions, out of a score of 100, power distance (POW_DIST) is 45.13; individualism (INDIV) is 72.27; masculinity (MASCUL) is 61.50; uncertainty avoidance (UNC_AVOID) is 56.70; long-term orientation (LONG_ORIENTATION) is 48.25; and indulgence (INDULG) is 59.56. Most of the cultural dimensions ( 4 out of 6 ) are higher than 50, and the remainder ( 2 out of 6 ) are near 50. Firm size (SIZE) is, on average, 9.63 (log of total assets), with return on assets (ROA) 6.58\% and leverage (LEVERAGE) 69.71\%. Additionally, board size (B_SIZE) is 10.87 board members, and the percentage of independent directors (B_INDEP) is, on average, 50.73\%. Firms are domiciled in countries where their governance is 6.06 out of 10; the gross domestic product is 12.51 and the liquidity of firms is, on average, $1.76 \%$. Finally, $14.11 \%$ of the companies in the sample belong to the basic materials sector, $10.11 \%$ to consumer non-cyclical, $9.59 \%$ to energy, $21.58 \%$ to industrials, $6 \%$ to utilities, $19.19 \%$ to consumer cyclicals, $7.87 \%$ to healthcare, $8.20 \%$ to technology and $3.35 \%$ to telecommunication services.

\section{[Insert Table 4]}

In Table 5, we provide the correlation coefficients for analysing whether multicollinearity is a concern in this research. None of the coefficients is higher than 0.8. Therefore, in line with Archambeault and DeZoort (2001), we conclude that multicollinearity is not a problem in this study.

[Insert Table 5]

\subsection{Multivariate analysis}

Table 6 shows the findings for checking all the hypotheses proposed. In Model 1, we examine whether the cultural dimension power distance (POW_DIST) is positively associated with 
organisational innovation. As expected, the coefficient of the power distance variable is positive, and it is statistically significative. This finding leads us to not reject the first hypothesis, which suggests that firms operating in cultures where there are high levels of power distance are more likely to innovate than those in countries with lower levels. This evidence is consistent with Vecchi and Brennan (2009) and Zhang and Zhour (2015). Those in societies with high levels of power distance are more likely to follow formal codes of conduct and are reluctant to go against the word of their superiors. Thus, our result supports the view that companies domiciled in contexts with a greater power distance tend to invest more in innovation because it will be easier to break any barriers to innovation, showing that they are interested in developing new products and in improving their production processes.

In Model 2, we analyse whether the probability of investing in innovation is higher in individualistic cultures. The variable individualism, INDIV, shows a negative sign, contrary to our predictions, and it is statistically significant. According to this result, the second hypothesis has to be rejected. Thus, companies operating in societies which focus on the individual are less likely to invest in innovation. This evidence suggests, in contrast to past evidence (e.g. Shane, 1993; Jones and Teegen, 2001), that individualistic cultures, where individuals have more freedom to provide new and creative ideas and opinions, do not tend to innovate more, which goes against organisational growth. Our finding is in line with Taylor and Wilson (2012), who support the view that in collectivist cultures, with higher levels of nationalism and patriotism, firms are more likely to innovate. In individualist societies, there is a higher expectation of individual freedom, approval of selfenrichment, and greater tolerance, but it seems that innovation decisions require collective support and conservative and traditional values.

The effect of masculinity cultures on innovation is examined in Model 3. The variable masculinity, MASCUL, is positive and statistically significant. This leads us to not reject the third hypothesis, which proposes that companies domiciled in masculine contexts tend to invest more in innovation. Our evidence is consistent with Efrat (2014), who suggests that masculinity contexts are more positive, safer and more proactive in taking on challenges and tend to have initiative, which results in higher levels of innovation, such as new products. This evidence is also supported by Jones and Davis (2000). In a masculine culture, members tend to value personal attainment, money and success, and are more competitive and aggressive than in feminine cultures, where members tend to care for others, place greater importance on quality of life and are more nurturing, modest and humble. Thus, in cultures where the presence of the male prevails, particularly in organisations, there is a greater likelihood of innovation in new products and production processes. Male cultural values seem to be more closely associated with innovation than female ones.

In Model 4, we analyse whether companies operating in cultures of uncertainty avoidance invest more or less in innovation. The variable uncertainty avoidance, UNC_AVOID, exhibits a positive sign, contrary to our predictions, and is statistically significant. Therefore, the fourth 
hypothesis has to be rejected. Our finding suggests that firms domiciled in uncertainty avoidance contexts tend to invest more in innovation than those in cultures with less uncertainty, contrary to past evidence (e.g. Gaspay et al., 2008; Chen et al., 2017; Tian et al., 2018). The dimension of uncertainty avoidance reflects the fact that individuals feel threatened or uncomfortable in uncertain circumstances and, as a result, these members will try to achieve conformity through contexts and a belief system created by them. In societies where uncertainty avoidance is high, members value security, place greater emphasis on written rules and consensus and do not tolerate deviations from the rule, while societies with low levels of uncertainty avoidance feel less need for written norms and are tolerant of deviations from the norm. These features suggest a higher investment in innovation in cultures which have lower uncertainty avoidance than those in cultures with higher uncertainty avoidance, in contrast with our evidence. Our conclusion can be justified because firms operating in cultures with high uncertainty have to innovate in new products and production processes in order to protect themselves from uncertainty and survive.

In Mode 5, we scrutinise the effect of long-term orientation dimension on innovation. The coefficient of the variable long term orientation, LONG_ORIENATION, is positive, as expected, and is significant from a statistical point of view. Thus, the fifth hypothesis cannot be rejected. This finding shows that companies domiciled in long-term orientation contexts are more likely to invest in innovation, in line with Rhyne et al. (2002) and Rujirawanich et al. (2011), who also document a positive association between the long-term cultural dimension and innovation. Innovation in business is a process which requires time because it translates an invention or idea into a service or good that creates value and tries to satisfy the expectations and needs of the clients. Long-term orientation represents the extent to which a society places greater value on the honesty, self-discipline, learning, adaptiveness and accountability of its members. In cultures with a long-term orientation, members are instilled with the tendency to be prudent and humble; they are persistent in striving to achieve their goals and are not encouraged to be self-assertive. In societies with a short-term orientation, the main values are achievement, freedom, and thinking for oneself; rights and personal needs will determine personal loyalties. This supports the view that firms operating in societies with a long-term orientation will invest more in innovation.

In the final model, Model 6, we examine how innovation is affected in indulgent cultures. The variable indulgence, INDULG, exhibits a negative sign, contrary to our predictions, but is not statistically significant. Then, the sixth hypothesis has to be rejected. Our evidence does not support the idea that the more indulgent a society is, the higher the level of innovation. Indulgence stands for a society that allows gratification of basic and natural human drives related to enjoying life and having fun. Restraint stands for a society that suppresses gratification of needs and regulates it by means of strict social norms. Indulgent cultures tend to focus more on individual happiness and well-being; leisure time is more important and there is greater freedom and personal control. This is in contrast with restrained cultures, where positive emotions are less freely expressed and happiness, freedom and 
leisure are not given the same importance. These reasonings suggest a higher likelihood of investing in innovation in indulgent contexts than in restrictive cultures, but our evidence shows that innovation is not affected by the cultural dimension of indulgence. Thus, operating in indulgent vs restrictive cultures is not a factor impacting innovation. It seems that communities living in indulgent and restrictive societies do not associate innovation with higher or lower gratification, individual happiness or leisure time, among others.

Focusing on the control variables, in all models return on assets (ROA) negatively affects innovation, except for Model 4, where ROA is not statistically significant. The leverage of firms (LEVERAGE) is negatively associated with innovation in Models 2, 3, 5 and 6 and positively in Model 4. On the other hand, board size (B_SIZE) and board independence (B_INDEP) have a positive impact on innovation: board size in Model 3 and board independence in Models 4 and 5. The gross domestic product of the country (GDP) affects innovation negatively in Model 1 and positively in Model 4. Examining the results by sector, innovation is positively affected by all industries in the power distance model, except the industrials, utilities and consumer cyclical sectors, which are not statistically significant. The rest of control variables are not statistically significant.

\section{Conclusions and future directions}

In this research, we aim to explore whether the cultural dimensions where firms are domiciled affect their investment in innovation. To this end, we use the six cultural dimensions of Hofstede (power distance, individualism, masculinity, uncertainty avoidance, long-term orientation and indulgence). Drawing on institutional theory, companies operating in the same context will tend to behave in a similar way because the institutional context for these firms will be the same.

Our results find that innovation is positively affected by the cultural dimensions of power distance, masculinity, uncertainty avoidance and long-term orientation, and negatively affected by individualism. Additionally, the indulgence dimension does not have an impact on innovation. Thus, firms domiciled in powerful, masculine, uncertain and long-term orientation societies will be more likely to invest in innovation, and less likely to do so if they operate in individualist cultures. Whether a society is more or less indulgent is not a determining factor from an innovation point of view, because innovation levels are independent of this cultural dimension.

Our results have several implications. Firstly, our evidence supports the notion that the culture of the country where firms are domiciled is a relevant factor in improving or decreasing innovation. In this regard, companies, particularly management, which engage in innovation strategies should consider the cultural factors prevalent where their companies are operating. This will also allow firms to show their commitment to their stakeholders, especially their customers, because more innovation implies new products. Secondly, policy-makers have the power to institutionalise behaviours by recommendations, rules and laws. Given the positive effects that innovation can have on products and services, policy-makers should encourage more investment in innovation in individualist and indulgent 
societies, where innovation is decreased or not affected, respectively. Thirdly, this study sheds new light on the repercussions of culture on innovation, but other factors also have an influence. We encourage other researchers to extend our research, examining whether other factors such as board gender diversity, corporate governance mechanisms or political situation of the country, among other factors, affect innovation. Finally, we provide new evidence relevant to the existing body of literature focused on institutional theory, because most papers show the positive effect of individualist and indulgent cultures on innovation and the negative impact of the uncertainty avoidance dimension, while our findings are contrary to these three points. The cultural dimension of indulgence does not influence organisations when innovation strategies are defined, and individualism and uncertainty avoidance cultural factors affect innovation in a manner contrary to what would be expected. More evidence will shed new light on how cultural dimensions impact on innovation.

Several lines of future research can be derived from this study. Firstly, it would be interesting to explore whether these cultural factors affect innovation in financial entities, which were excluded from our sample. These entities can innovate in the products they provide to their clients and, therefore, more evidence about this topic in this industry may reinforce our conclusions. Secondly, it would be also instructive to examine how other institutional factors impact on innovation, such as the political stability of the country, the varieties of capitalism in the country, the transparency and accountability of the country or the efficiency of the judicial system. Finally, other R\&D intensity conventional determinants may be also explored, such as human capital or export propensity, among others. Such an analysis may give an additional perspective on the multiple factors affecting R\&D intensity beyond Hofstede's cultural dimensions.

\section{Notes}

${ }^{1}$ The cultural insights website of Geert Hofstede can be accessed at: https://www.geert-hofstede.com/

\section{Notes}

${ }^{1}$ The cultural insights website of Geert Hofstede can be accessed at: https://www.geert-hofstede.com/

\section{References}

Allred, B.B., \& Swan, K.S. (2004). Global versus multidomestic: culture's consequences on innovation. Management International Review, 44 (1), 81-105.

Ambos, B., \& Schlegelmilch, B. B. (2008). Innovation in Multinational Firms: Does Cultural Fit Enhance Performance?. Management international review, 48 (2), 189-206.

Archambeault, D., \& DeZoort, F. T. (2001). Auditor opinion shopping and the audit committee: An analysis of suspicious auditor switches. International Journal of Auditing, 5(1), 33-52.

Archibugi, D., \& Planta, M. (1996). Measuring technological change through patents and innovation surveys. Technovation, 16(9), 451-519.

Azar, G., \& Drogendijk, R. (2016). Cultural distance, innovation and export performance. European Business Review, 28(2), 176-207.

Balsmeier, B., Fleming, L., \& Manso, G. (2017). Independent boards and innovation. Journal of Financial Economics, 123(3), 536-557. 
Baregheh, A., Rowley, J., \& Sambrook, S. (2009). Towards a multidisciplinary definition of innovation. Management Decision, 47 (8), 1323-1339.

Baskerville, R.F. (2003). Hofstede never studied culture. Accounting, Organizations and Society, 28, 1-4.

Bradley, F., Gao, Y., \& Sousa, C. (2013). A natural science approach to investigate cross-cultural managerial creativity. International Business Review, 22 (5), 839-855.

Brem, A., Maier, M., \& Wimschneider, C. (2016). Competitive advantage through innovation: the case of Nespresso. European Journal of Innovation Management, 19 (1), 133-148.

Budde-Sung, A. (2013). The Invisible Meets the Intangible: Culture's Impact on Intellectual Property Protection. Journal of Business Ethics, 117, 345-359.

Chaiporn, V., \& Olimpia, C. R. (2016). Short- and long-run effects of internationalization and R\&Dintensity on firm performance. Journal of Multinational Financial Management, 34, 28 45.

Chouaibi, J., Boujelbene, Y., \& Affes, H. (2009). Characteristics of the board of directors and involvement in innovation activities: A cognitive perspective. Corporate Board: Role, Duties and Composition, 5(3), 34-44.

Conner, K.R. (1991). A historical comparison of resource-based theory and five schools of thought within industrial organization economics: Do we have a new theory of the firm? Journal of Management, 17(1),121-154.

Chen, J., Sun, P., \& McQueen, R. (2010). The impact of national cultures on structured knowledge transfer. Journal of Knowledge Management, 14 (2), 228-242.

Chen, Y., Podolski, E.J., \& Veeraraghavan, M. (2017). National culture and corporate innovation. Pacific-Basin Finance Journal, 43, 173-187.

Davenport, T.H., \& Prusak, L. (2000). Working Knowledge - How Organizations Manage What They Know, Harvard Business School Press, Boston, MA.

Dedahanov, A., Lee, D., Rhee, J., \& Yoon, J. (2016). Entrepreneur's paternalistic leadership style and creativity: the mediating role of employee voice. Management Decision, 54 (9), 2310-2324.

De Mooij, M., \& Hofstede, G. (2010). The Hofstede model: Applications to global branding and advertising strategy and research. International Journal of Advertising, 29 (1), 85-110.

Desmarchelier, B., \& Fang, E. (2016). National culture and innovation diffusion. Technological Forecasting and Social Change, 105, 121-128.

Dimaggio, P. J., \& Powell, W. (1983). The iron cage revisited: Institutional isomorphism and collective rationality in organizational fields. American Sociological Review, 48, 147-160.

Efrat, K. (2014). The direct and indirect impact of culture on innovation. Technovation, 34 (1), 12-20.

Erez, M., \& Nouri, R. (2010). Creativity: the influence of cultural, social, and work contexts. Management and Organization Review, 6 (3), 351-370.

Gallego-Álvarez, I., \& Ortas, E. (2017). Corporate environmental sustainability reporting in the context of national cultures: A quartile regression approach. International Business Review, 2, 337-353.

Gaspay, A., Dardan, S., \& Legorreta, L. (2008). Software of the mind-A review of applications of Hofstede's theory to IT research. Journal of Information Technology Theory and Application, 9, 1-37.

Griffith, D., \& Rubera, G. (2014). A cross-cultural investigation of new product strategies for technological and design innovations. Journal of International Marketing, 22 (1), 5-20.

Gupta, D.R., Veliyath, R., \& George, R. (2018). Influence of national culture on IPO activity. Journal of Business Research, 90, 226-246

Hoecklin, L. (1996). Managing Cultural Differences: Strategies of Competitive Advantage, AddisonWesley, Wokingham.

Hofstede, G. (1980). Culture's consequences: International differences in work-related values. Newbury Park: Sage Publications.

Hofstede, G.H. (1983). The Cultural Relativity of Organizational Practices and Theories. Journal of International Business Studies, 82, 76-88.

Hofstede, G. (2001). Culture's consequences: Comparing values, behaviors, institutions, and organizations across nations. Thousand Oaks: Sage Publications. 
Hofstede, G., \& Hofstede, G.J. (2005).Cultures and Organizations: Software of the Mind (2ndEdition).USA: McGraw-Hill.

Hofstede, G., Hofstede, G. J., \& Minkov, M. (2010).Cultures and Organizations: Software of the Mind(10th Edition).USA: McGraw-Hill.

Hoskisson, R. E., Hitt, M. A., Johnson, R. A. \& Moesel, D. D. (1993). Construct validity of an objective (Entropy) categorical measure of diversification strategy. Strategic Management Journal, 14, 215-235.

Ismail, M., \& Lu, H.S. (2014). Cultural values and career goals of the millennial generation: An integrated conceptual framework. The Journal of International Management Studies, 9 (1), 3849.

Jones, M. (2007). Hofstede - Culturally questionable?, Oxford Business \& Economics Conference. Oxford, UK, 24-26 June.

Jones, G., \& Davis, H. (2000). National culture and innovation: implications for locating global R\&D operations. Management International Review, 40 (1), 11-39.

Jones, G. K., \& Teegen, H. J. (2001). Global R\&D activity of U.S. MNCs: Does National Culture Affect Investment Decisions?. Multinational Business Review, 9 (2), 1-7.

Kaasa, A., \& Vadi, M. (2010). How does culture contribute to innovation? Evidence from European countries. Economics of innovation and new technology, 19 (7), 583-60.

Kirkman, B. L., Lowe, K. B., \& Gibson, C. B. (2006). A quarter century of Culture's Consequences: a review of empirical research incorporating Hofstede's cultural values framework. Journal of International Business Studies, 37(3), 285-320.

Kleinknecht, A., van Montfort, K., \& Brouwer, E. (2002). The non-trivial choice between innovation indicators. Economics of Innovation and New Technology, 11(2), 109-121.

Lerner, J., \& Wulf, J. (2007). Innovation and incentives: Evidence from corporate R\&D. The Review of Economics and Statistics, 89, 634-644.

Lorca, P., \& de Andrés, J. (2019). The Importance of Cultural Factors in R\&D Intensity. CrossCultural Research, 53 (5), 483-507.

Lynn, M., \& Gelb, B.D. (1996). Identifying Innovative National Markets for Technical Consumer Goods. International Marketing Review, 13(6), 43-57.

Magnier- Watanabe, R., \& Senoo, D. (2010). Shaping knowledge management: organization and national culture. Journal of Knowledge Management, 14 (2) 214-227.

Min, B.S., \& Smyth, R. (2016). How does leverage affect R\&D intensity and how does R\&D intensity impact on firm value in South Korea? Applied Economics, 48(58), 5667-5675.

Minkov. M. (2018). A revision of Hofstede's model of national culture: Old evidence and new data from 56 countries. Cross-Cultural and Strategic Management, 25(2), 231-256.

Miska, Ch., Szőcs, I., \& Schiffinger, M. (2018). Culture's effects on corporate sustainability practices: A multi-domain and multi-level view. Journal of World Business, 53(2), 263-279.

Nam, D.-I., Parboteeah, K.P., Cullen, J.B., and Johnson, J.L. (2014). Cross-national differences in firms undertaking innovation initiatives: An application of institutional anomie theory. Journal of International Management, 20(2), 91-106.

Naqshbandi, M. (2016). Managerial ties and open innovation: examining the role of absorptive capacity. Management Decision, 54 (9), 2256-2276.

Nekhili, M., and Gatfaoui, H. (2013). Are demographic attributes and firm characteristics drivers of gender diversity? Investigating women's positions on French boards of directors. Journal of Business Ethics, 118(2), 227-249.

Orij, R. (2010). Corporate social disclosures in the context of national cultures and stakeholder theory. Accounting, Auditing \& Accountability Journal, 23 (7), 868-889.

Parboteeah, K.P., \& Cullen, J.B. (2003). Social Institutions and Work Centrality: Explorations Beyond National Culture. Organization Science, 14 (2), 137-148.

Pellegrino, G., \& Piva, M. (2019). Innovation, industry and frm age: are there new knowledge production functions?. Euroasian Business Review, https://doi.org/10.1007/s40821-01900129-6

Peng., Y-S., \& Lin., S-S. (2009). National culture, economic development, population growth and environmental performance: The mediating role of education. Journal of Business Ethics, 90, 203-219. 
Rattrie, L.T., Kittler, M.G., \& Paul, K.I. (2020). Culture, Burnout, and Engagement: A MetaAnalysis on National Cultural Values as Moderators in JD- R Theory. Applied Psychology, 69, 176-220.

Rhyne, L., Teagarden, M., \& Van den Panhuyzen, W. (2002). Technology-based competitive strategies: the relationship of cultural dimensions to new product innovation. The Journal of High Technology Management Research, 13 (2), 249-277.

Richardson, P. J., \& Boyd, R. (2005). Not by genes alone: How culture transformed human evolution. Chicago: The University of Chicago Press.

Rohlfer, Y., \& Zhang, Y. (2016). Cultural studies in international business: paradigmatic shifts, European Business Review, 28 (1), 39-62.

Rujirawanich, P., Addison, R., \& Smallman, C. (2011). The effects of cultural factors on innovation in a Thai SME. Management Research Review, 34 (12), 1264-1279.

Scott, W. R. (2001). Institutions and organizations. London: Sage Publications.

Scott, W.R. (2008). Approaching Adulthood: The Maturing of Institutional Theory. Theory and Society, 37 (5), 427-442.

Shane, S. (1993). Cultural influences on national rates of innovation. Journal of Business Venturing, 8 (1), 59-73.

Sivak, R., Caplanova, A., \& Hudson, J. (2011) The impact of governance and infrastructure on innovation. Post-Communist Economies, 23(02), 203-217

Smale, T. (2016). Why national culture should be at the heart of innovation management, Technology Innovation Management Review, 6 (4), 18-25.

Schmitt, D.P., Allik, J., McCrae, R.R., \& Benet-Martinez, V. (2007). The geographic distribution of Big Five personality traits: patterns and profiles of human self-description across 56 nations. Journal of Cross-Cultural Psychology, 38 (2), 173-212.

Song, H., Zhang-Zhang, Y., Tian, M., Rohlfer, S., \& Sharkasi, N. (2019). Culture and regional innovation performance: an exploration in China. Chinese Management Studies, 13(2), $97-$ 420.

$\mathrm{Su}, \mathrm{S}$. (2006). Cultural differences in determining the ethical perception and decision-making of future accounting professionals: a comparison between accounting students from Taiwan and the United States. The Journal of American Academy of Business, 9(1), 147-158.

Sully de Luque, M., \& Javidan, M. (2004). Uncertainty avoidance. In J. S. House, P. J. Hanges, M. Javidan, P. W. Dorfman, \& V. Gupta (Eds.), Culture, leadership, and organizations: The GLOBE study of 62 societies (pp. 602-653). Thousand Oaks, CA: Sage.

Syed, H., \& Malik, A.N. (2014). Comparative study of effect of culture on technology adoption in Pakistan and USA. The Business and Management Review, 5, 1, 42-51.

Taylor, M.Z., \& Wilson, S. (2012). Does culture still matter?: The effects of individualism on national innovation rates. Journal of Business Venturing, 27(2), 234-247.

Tsakumis, G.T. (2007). The influence of culture on accountants' application of financial reporting rules. Abacus, 4, 27-48.

Tian, M., Deng, P., Zang, Y., \& Salmador, M.P. (2018). How does culture influence innovation? A systematic literature review. Management Decision, 56 (5), 1088-1107.

Van Everdingen, Y.M., \& Waarts, E. (2003). The Effect of National Culture on the Adoption of Innovations. Marketing Letters, 14 (3), 217-232.

Vecchi, A., \& Brennan, L. (2009). A cultural perspective on innovation in international manufacturing. Research in International Business and Finance, 23 (2), 181-192.

Vitell, S.J. (2003). Consumer Ethics Research: Review, Synthesis and Suggestions for the Future. Journal of Business Ethics, 43, 33-47.

Vollero, A., Siano, A., Palazzo, M., \& Amabile, S. (2020). Hoftsede's cultural dimensions and corporate social responsibility in online communication: Are they independent constructs? Corporate Social Responsibility and Environmental Management, 27, 53- 64.

Waarts, E., \& Van Everdingen, Y. (2005). The influence of national culture on the adoption status of innovations: An empirical study of firms across Europe. European Management Journal, 23, 601-610. 
Waldman, D., de Luque, S., Washburn, N., \& House, R. (2006). Cultural and leadership predictors of corporate social responsibility values of top management: A GLOBE study of 15 countries. Journal of International Business Studies, 37, 823-837.

Wei-Han, L. (2019). National culture effects on stock market volatility level. Empirical Economics, 57(4), 1229-1253.

Wollan, M. L., Sully de Luque, M., \& Grünhagen, M. (2009). Motives for helping: Exploring cultural influences on extra-role behaviour. Multinational Business Review, 17(1), 99-119.

Yang, T., \& Li, C. (2011). Competence exploration and exploitation in new product development: the moderating effects of environmental dynamism and competitiveness. Management Decision, 49 (9), 1444-1470.

Zhang, M. (2011). Firm- level performance impact of IS support for product innovation. European Journal of Innovation Management, 14(1), 118-132.

Zhang, Y., \& Zhou, Y. (2015). The Source of Innovation in China, Palgrave MacMillan, Hampshire. 
Table 1

Number of observations by country

\begin{tabular}{|c|c|c|c|}
\hline Country & Observations & Percentage & Cum. \\
\hline Australia & 789 & $6.49 \%$ & $6.49 \%$ \\
\hline Austria & 41 & $0.34 \%$ & $6.83 \%$ \\
\hline Belgium & 95 & $0.78 \%$ & $7.61 \%$ \\
\hline Brazil & 240 & $1.98 \%$ & $9.59 \%$ \\
\hline Canada & 1,106 & $9.10 \%$ & $18.69 \%$ \\
\hline Chile & 110 & $0.91 \%$ & $19.60 \%$ \\
\hline China & 322 & $2.65 \%$ & $22.25 \%$ \\
\hline Denmark & 107 & $0.88 \%$ & $23.13 \%$ \\
\hline Finland & 142 & $1.17 \%$ & $24.29 \%$ \\
\hline France & 551 & $4.53 \%$ & $28.83 \%$ \\
\hline Germany & 403 & $3.32 \%$ & $32.15 \%$ \\
\hline Greece & 6 & $0.05 \%$ & $32.19 \%$ \\
\hline Hong Kong & 128 & $1.05 \%$ & $33.25 \%$ \\
\hline India & 155 & $1.28 \%$ & $34.52 \%$ \\
\hline Ireland & 173 & $1.42 \%$ & $35.95 \%$ \\
\hline Italy & 121 & $1.00 \%$ & $36.94 \%$ \\
\hline Japan & 1,727 & $14.21 \%$ & $51.16 \%$ \\
\hline Mexico & 123 & $1.01 \%$ & $52.17 \%$ \\
\hline Netherlands & 212 & $1.74 \%$ & $53.91 \%$ \\
\hline New Zealand & 50 & $0.41 \%$ & $54.32 \%$ \\
\hline Norway & 70 & $0.58 \%$ & $54.90 \%$ \\
\hline Portugal & 29 & $0.24 \%$ & $55.14 \%$ \\
\hline Spain & 168 & $1.38 \%$ & $56.52 \%$ \\
\hline Sweden & 255 & $2.10 \%$ & $58.62 \%$ \\
\hline Switzerland & 390 & $3.21 \%$ & $61.83 \%$ \\
\hline Thailand & 94 & $0.77 \%$ & $62.60 \%$ \\
\hline United Kingdom & 1,119 & $9.21 \%$ & $71.81 \%$ \\
\hline United States & 3,425 & $28.19 \%$ & $100.00 \%$ \\
\hline Total & 12,151 & $100 \%$ & \\
\hline
\end{tabular}

Table 2

Number of observations by activity sector

\begin{tabular}{|c|c|c|c|}
\hline $\begin{array}{l}\text { TRBC economic sector } \\
\text { name }\end{array}$ & $\begin{array}{c}\text { Number of } \\
\text { observations }\end{array}$ & Percentage & Cum. \\
\hline Basic Materials & 1,714 & $14.11 \%$ & $14.11 \%$ \\
\hline Consumer Cyclicals & 2,332 & $19.19 \%$ & $33.30 \%$ \\
\hline Consumer Non-Cyclicals & 1,229 & $10.11 \%$ & $43.41 \%$ \\
\hline Energy & 1,165 & $9.59 \%$ & $53.00 \%$ \\
\hline Healthcare & 956 & $7.87 \%$ & $60.87 \%$ \\
\hline Industrials & 2,622 & $21.58 \%$ & $82.45 \%$ \\
\hline Technology & 996 & $8.20 \%$ & $90.65 \%$ \\
\hline Telecommunications & 407 & $3.35 \%$ & $94.00 \%$ \\
\hline \multicolumn{4}{|l|}{ Services } \\
\hline Utilities & 730 & $6.00 \%$ & $100 \%$ \\
\hline Total & 12,151 & $100 \%$ & \\
\hline
\end{tabular}


Table 3

Variables description

\begin{tabular}{|c|c|}
\hline Variables & Description \\
\hline RD_INTENSITY & Ratio between Research and Development expenses and total sales \\
\hline POW_DIST & $\begin{array}{l}\text { Power distance is one of the six culture dimensions addressed by Hostfede (2010) and } \\
\text { ranges from } 0 \text { to } 100\end{array}$ \\
\hline INDIV & $\begin{array}{l}\text { Individualism is one of the six culture dimensions addressed by Hostfede (2010) and } \\
\text { ranges from } 0 \text { to } 100\end{array}$ \\
\hline MASCUL & $\begin{array}{l}\text { Masculinity is one of the six culture dimensions addressed by Hostfede (2010) and ranges } \\
\text { from } 0 \text { to } 100\end{array}$ \\
\hline UNC_AVOID & $\begin{array}{l}\text { Uncertainity avoidance is one of the six culture dimensions addressed by Hostfede (2010) } \\
\text { and ranges from } 0 \text { to } 100\end{array}$ \\
\hline LONG_ORIENTATION & $\begin{array}{l}\text { Long-term orientation is one of the six culture dimensions addressed by Hostfede (2010) } \\
\text { and ranges from } 0 \text { to } 100\end{array}$ \\
\hline INDULG & $\begin{array}{l}\text { Indulgence is one of the six culture dimensions addressed by Hostfede (2010) and ranges } \\
\text { from } 0 \text { to } 100\end{array}$ \\
\hline SIZE & The log of total assets \\
\hline ROA & Operate income before interests and taxes over total assets \\
\hline LEVERAGE & Debt over total assets \\
\hline B_SIZE & Number of directors on board \\
\hline B_INDEP & $\begin{array}{l}\text { Proportion of independent directors on boards= Total number of independent directors on } \\
\text { boards/ Total number of directors on boards }\end{array}$ \\
\hline GOVERN & $\begin{array}{l}\text { Governance of the country is the ratio between the addition of } 4 \text { components, which range } \\
\text { from } 0 \text { to } 10 \text {, and the total number of components (4). The four components are (a) } \\
\text { government consumption, (b) transfers and subsidies, (c) government enterprises and } \\
\text { investment and (d) top marginal tax rate. Governance indicates the extent to which } \\
\text { countries rely on the political process to allocate resources and goods and services. }\end{array}$ \\
\hline LIQUIDITY & Ratio between total current assets and total current liabilities \\
\hline GDP & The log of gross domestic product of a country \\
\hline BASIC MATERIALS & Dummy variable: $1=$ Basic Materials; $0=$ Otherwise \\
\hline $\begin{array}{l}\text { CONSUMER } \\
\text { CYCLICAL }\end{array}$ & Dummy variable: $1=$ Consumer Non-Cyclical; $0=$ Otherwise \\
\hline ENERGY & Dummy variable: $1=$ Energy; $0=$ Otherwise \\
\hline INDUSTRIALS & Dummy variable: $1=$ Industrial; $0=$ Otherwise \\
\hline UTILITIES & Dummy variable: $1=$ Utilities; $0=$ Otherwise \\
\hline CONSUMER CYCLICAL & Dummy variable: $1=$ Consumer Cyclical; $0=$ Otherwise \\
\hline HEALTHCARE & Dummy variable: $1=$ Healthcare; $0=$ Otherwise \\
\hline TECHNOLOGY & Dummy variable: $1=$ Technology; $0=$ Otherwise \\
\hline $\begin{array}{l}\text { TELECOMMUNICATION } \\
\text { SERVICES }\end{array}$ & Dummy variable: $1=$ Telecommunication Services; $0=$ Otherwise \\
\hline
\end{tabular}


Table 4

Descriptive analysis

\begin{tabular}{lccc}
\hline \multicolumn{1}{c}{ Variable } & Obs & Mean & $\begin{array}{c}\text { Standard } \\
\text { Deviation }\end{array}$ \\
\hline RD_INTENSITY & 12,151 & $2.21 \%$ & $5.50 \%$ \\
POW_DIST & 12,151 & 45.13 & 13.31 \\
INDIV & 12,151 & 72.27 & 21.29 \\
MASCUL & 12,151 & 61.50 & 19.36 \\
UNC_AVOID & 12,151 & 56.70 & 20.56 \\
LONG_ORIENTATION & 12,151 & 48.25 & 24.18 \\
INDULG & 12,151 & 59.56 & 14.82 \\
SIZE & 12,151 & 9.63 & 1.47 \\
ROA & 12,151 & $6.58 \%$ & $7.46 \%$ \\
LEVERAGE & 12,151 & $69.71 \%$ & $61.85 \%$ \\
B_SIZE & 12,151 & 10.87 & 3.58 \\
B_INDEP & 12,151 & $50.73 \%$ & $34.91 \%$ \\
GOVERN & 12,151 & 6.06 & 1.03 \\
LIQUIDITY & 12,151 & $1.76 \%$ & $3.89 \%$ \\
GDP & 12,151 & 12.51 & 0.55 \\
BASIC MATERIALS & 12,151 & $14.11 \%$ & $34.80 \%$ \\
CONSUMER NON-CYCLICAL & 12,151 & $10.11 \%$ & $30.15 \%$ \\
ENERGY & 12,151 & $9.59 \%$ & $29.44 \%$ \\
INDUSTRIALS & 12,151 & $21.58 \%$ & $41.14 \%$ \\
UTILITIES & 12,151 & $6.00 \%$ & $23.76 \%$ \\
CONSUMER CYCLICAL & 12,151 & $19.19 \%$ & $39.38 \%$ \\
HEALTHCARE & 12,151 & $7.87 \%$ & $26.92 \%$ \\
TECHNOLOGY & 12,151 & $8.20 \%$ & $27.43 \%$ \\
TELECOMMUNICATION SERVICES & 12,151 & $3.35 \%$ & $18.00 \%$ \\
\hline
\end{tabular}

\footnotetext{
Mean and standard deviation. RD_INTENSITY is the ratio between Research and Development expenses and the total sales; POW_DIST represents the power distance, one of the six culture dimensions addressed by Hostfede (2010) and ranges from 0 to 100; INDIV represents the individualism, one of the six culture dimensions addressed by Hostfede (2010) and ranges from 0 to 100; MASCUL represents the masculinity, one of the six culture dimensions addressed by Hostfede (2010) and ranges from 0 to 100; UNC_AVOID represents the uncertainity avoidance, one of the six culture dimensions addressed by Hostfede (2010) and ranges from 0 to 100; LONG_ORIENTATION represents the long-term orientation, one of the six culture dimensions addressed by Hostfede (2010) and ranges from 0 to 100; INDULG represents the indulgence, one of the six culture dimensions addressed by Hostfede (2010) and ranges from 0 to 100; SIZE is the log of total assets; ROA is the operate income before interests and taxes over total assets; LEVERAGE is the debt over total assets; B_SIZE is the number of directors on board; B INDEP is the proportion of independent directors on boards= Total number of independent on boards/ Total number of directors on boards; GOVERN is the ratio between the addition of 4 components, which range from 0 to 10 , and the total number of components (4). The four components are (a) government consumption, (b) transfers and subsidies, (c) government enterprises and investment and (d) top marginal tax rate. Governance indicates the extent to which countries rely on the political process to allocate resources and goods and services; LIQUIDITY is the ratio between total current assets and total current liabilities; GDP is the log of gross domestic product of the country; BASIC MATERIALS is a dummy variable: $1=$ Basic Materials; $0=$ Otherwise; CONSUMER NONCYCLICAL is a dummy variable: $1=$ Consumer Non-Cyclical; $0=$ Otherwise; ENERGY is a dummy variable: $1=$ Energy; $0=$ Otherwise; ; INDUSTRIALS is a dummy variable: $1=$ Industrial; $0=$ Otherwise; UTILITIES is a dummy variable: $1=$ Utilities; $0=$ Otherwise; CONSUMER CYCLICAL is a dummy variable: $1=$ Consumer Cyclical; $0=$ Otherwise; HEALTHCARE is a dummy variable: $1=$ Healthcare; $0=$ Otherwise; TECHNOLOGY is a dummy variable: $1=$ Technology; $0=$ Otherwise and TELECOMMUNICATION SERVICES is a dummy variable: $1=$ Telecommunication Services; $0=$ Otherwise.
} 
Table 5

Correlation matrix

\begin{tabular}{|c|c|c|c|c|c|c|c|c|c|c|c|c|c|c|c|c|c|c|c|c|c|c|c|c|}
\hline & (1) & (2) & (3) & (4) & (5) & (6) & (7) & (8) & (9) & (10) & (11) & (12) & (13) & (14) & (15) & (16) & (17) & (18) & (19) & (20) & (21) & (22) & (23) & (24) \\
\hline RD_INTENSITY (1) & 1.000 & & & & & & & & & & & & & & & & & & & & & & & \\
\hline POW_DIST (2) & -0.001 & 1.000 & & & & & & & & & & & & & & & & & & & & & & \\
\hline INDIV (3) & 0.002 & -0.344"st & 1.000 & & & & & & & & & & & & & & & & & & & & & \\
\hline MASCUL (4) & $0.133^{* * * *}$ & $0.075^{n s s+}$ & $-0.186^{6 * * *}$ & 1.000 & & & & & & & & & & & & & & & & & & & & \\
\hline UNC_AVOID (5) & $0.069 *=*$ & $0.387^{7+s+s}$ & 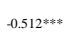 & $0.151^{1 * * *}$ & 1.000 & & & & & & & & & & & & & & & & & & & \\
\hline LONG_ORIENTATION (6) & $0.114^{* * * *}$ & $0.235^{* * * *}$ & 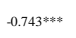 & $0.405^{\xi * * z}$ & $0.436^{* * * *}$ & 1.000 & & & & & & & & & & & & & & & & & & \\
\hline $\operatorname{INDULG}(7)$ & $-0.083^{* * * *}$ & $-0.610^{0 * * * *}$ & $0.577^{* * *}$ & $-0.364^{* 3 * * t}$ & $-0.459 * * *$ & $-0.596^{* * * * *}$ & 1.000 & & & & & & & & & & & & & & & & & \\
\hline $\operatorname{SIZE~(8)~}$ & $0.034^{* * *+4}$ & $0.217^{\mathrm{Nen+4}}$ & $-0.061^{1 * * *}$ & $0.118^{* * *}$ & $0.064^{* 2 * a}$ & $0.159^{* * *+}$ & $-0.288^{* *+*}$ & 1.000 & & & & & & & & & & & & & & & & \\
\hline $\mathrm{ROA}(9)$ & $0.022^{* * *}$ & $-0.093^{* * * *}$ & $0.176^{* * * *}$ & $-0.11^{2 * s+}$ & $-0.277^{1+* * *}$ & $-0.221 * * * *$ & $0.150^{0 * * *}$ & $-0.199^{* * * *}$ & 1.000 & & & & & & & & & & & & & & & \\
\hline LEVERAGE (10) & $-0.190 * * *$ & $0.076^{* * * *}$ & $-0.097=* *$ & $0.029 * * z$ & $0.092 * * *$ & $0.10^{1 * * *}$ & $-0.100 * *=$ & $0.303^{3 * * *}$ & $-0.352^{* * *}$ & 1.000 & & & & & & & & & & & & & & \\
\hline B_SIIZ (13) & $-0.030^{0 * * *}$ & $0.234^{* * *}$ & $-0.114^{* * * *}$ & $0.067^{7 * * *}$ & $0.062^{2 * * *}$ & $0.147^{7 * * *}$ & $-0.281=*$ & $0.503^{3 * * *}$ & $-0.087 * * *$ & $0.182^{2 * * *}$ & 1.000 & & & & & & & & & & & & & \\
\hline B_INDEP (12) & $0.018^{* *}$ & $-0.221^{1 * * * *}$ & $0.626^{* *=*}$ & $-0.280=* *$ & $-0.373^{* * *}$ & $-0.563^{* * * *}$ & $0.390^{0=* *}$ & -0.004 & $0.10^{0 * * * *}$ & $-0.050= \pm$ & $-0.122^{* * *}$ & 1.000 & & & & & & & & & & & & \\
\hline GOVERN (13) & $-0.076^{* * *}$ & $-0.015^{*}$ & $0.427 * *=$ & -0.001 & $-0.220= \pm$ & $-0.566^{* * *}$ & $0.186^{6 * *}$ & $-0.099_{1 * * *}$ & $0.200^{7 * * *}$ & $-0.111^{5 * *}$ & $-0.070= \pm$ & $0.31^{* * * *}$ & 1.000 & & & & & & & & & & & \\
\hline LеUIDITY (14) & $0.283^{* 2+*}$ & -0.004 & $0.040^{* * * s}$ & $0.046^{4 * *+}$ & $0.016^{*}$ & $-0.066^{* * t *}$ & 0.003 & $-0.280= \pm x$ & $0.238^{* * *}$ & $-0.400^{* t *}$ & $-0.176^{* * *}$ & $0.220^{* *}$ & $0.100^{* * * *}$ & 1.000 & & & & & & & & & & \\
\hline GDP (15) & $0.144^{* * *+}$ & $0.335^{*+s+4}$ & $0.503^{* * *+8}$ & $0.371^{1 * * *}$ & $-0.15^{5 * 48}$ & $-0.14^{9 * s+4}$ & $-0.184 * t=$ & $0.214^{* s * *}$ & -0.008 & 0.012 & $0.121^{1 * * *}$ & $0.220^{+2 * *}$ & $0.183^{* *+*}$ & $0.066^{* * * * 4}$ & 1.000 & & & & & & & & & \\
\hline BASIC MATERIALS (16) & $0.080^{0=*+2}$ & $-0.068^{8 * t *}$ & $-0.084^{* * * *}$ & -0.014 & $0.073^{* * * *}$ & 0.007 & $0.049 * * *$ & $-0.060^{* * t}$ & $-0.072^{4 t s}$ & $-0.023^{* *}$ & $-0.059 * t=$ & $-0.0311^{* * *+*}$ & $-0.018^{*}$ & $0.162^{2 * *+*}$ & $-0.134^{4 * * *}$ & 1.000 & & & & & & & & \\
\hline CONSUMER NON-CYCLLCAL (17) & $-0.16^{6 * * *}$ & 0.003 & 0.011 & -0.013 & -0.011 & $-0.022^{* 2 s+4}$ & $0.039^{9 * * *}$ & $0.024^{4 s * t}$ & $0.042^{2 * * *}$ & $0.048^{8 * *+*}$ & $0.070^{0=s *}$ & $-0.038^{8 * *+*}$ & 0.005 & $-0.090^{0 * * t}$ & $-0.015^{*}$ & $-0.16^{6 * * *}$ & 1.000 & & & & & & & \\
\hline ENERGY (18) & -0.014 & $0.023^{*=}$ & 0.005 & $-0.138^{* x *}$ & $-0.051^{1 * * *}$ & $-0.059=s *$ & $0.029 * * *$ & $0.086^{6 * *}$ & $0.022^{2 * *}$ & $-0.060^{* * *}$ & $-0.015^{*}$ & $0.110^{* * * *}$ & $0.017 *$ & $-0.091 * * * *$ & $-0.045^{5 * * *}$ & $-0.132^{2 * * *}$ & $-0.011^{1 * * * *}$ & 1.000 & & & & & & \\
\hline
\end{tabular}


RD_INTENSITY is the ratio between Research and Development expenses and the total sales; POW_DIST represents the power distance, one of the six culture dimensions addressed by Hostfede (2010) and ranges addressed by Hostfede (2010) and ranges from 0 to 100; UNC_AVOID represents the uncertainity avoidance, one of the six culture dimensions addressed by Hostfede (2010) and ranges from 0 to 100 ; LONG_ORIENTATION represents the long-term orientation, one of the six culture dimensions addressed by Hostfede (2010) and ranges from 0 to 100; INDULG represents the indulgence, one of the six culture dimensions addressed by Hostfede (2010) and ranges from 0 to 100; SIZE is the log of total assets; ROA is the operate income before interests and taxes over total assets; LEVERAGE is the debt over total assets; B_SIZE is the number of directors on board; B_INDEP is the proportion of independent directors on boards= Total number of independent on boards/ Total number of directors on boards; GOVERN is the ratio B_SIZE is and investment and (d) top marginal tax rate. Governance indicates the extent to which countries rely on the political process to allocate resources and goods and services; LIQUIDITY is the ratio between total current assets and total current liabilities; GDP is the log of gross domestic product of the country; BASIC MATERIALS is a dummy variable: $1=$ Basic Materials; $0=$ Otherwise; CONSUMER NON-CYCLICAL is a dummy variable: $1=$ Consumer Non-Cyclical; $0=$ Otherwise; ENERGY is a dummy variable: $1=$ Energy; $0=$ Otherwise; ; INDUSTRIALS is a dummy variable: $1=$ Industrial; $0=$ Otherwise; UTILITIES is a dummy variable: variable: $1=$ Consumer Non-Cyclical; $0=$ Otherwise; ENERGY is a dummy variable: $1=$ Energy; $0=$ Otherwise; $;$ INDUSTRIALS is a dummy variable: $1=$ Industrial; $0=$ Otherwise; UTILITIES is a dummy variable:
$1=$ Utilities; $0=$ Otherwise; CONSUMER CYCLICAL is a dummy variable: $1=$ Consumer Cyclical; $0=$ Otherwise; HEALTHCARE is a dummy variable: $1=$ Healthcare; $0=$ Otherwise; TECHNOLOGY is a dummy variable: $1=$ Technology; $0=$ Otherwise and TELECOMMUNICATION SERVICES is a dummy variable: $1=$ Telecommunication Services; $0=$ Otherwise. ${ }^{*}$ p-value $<0.1 * *$ p-value $<0.05 * * * p$-value $<0.01$. 
Table 6

Multivariate analysis results of the Generalized Method of Moments

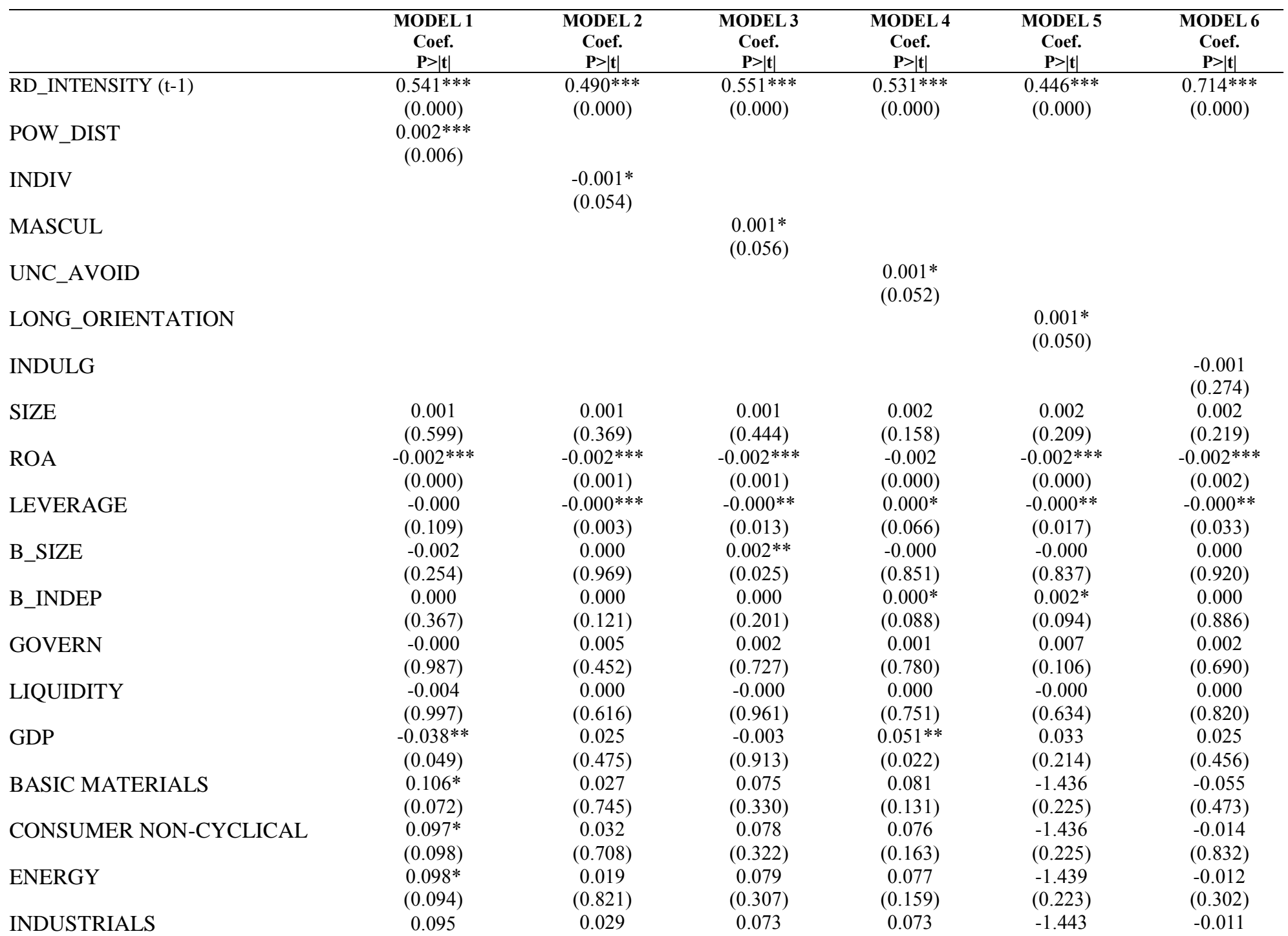




\begin{tabular}{|c|c|c|c|c|c|c|}
\hline UTILITIES & $(0.102)$ & $(0.732)$ & $(0.356)$ & $(0.182)$ & $(0.223)$ & $(0.343)$ \\
\hline \multirow[t]{2}{*}{ CONSUMER CYCLICAL } & 0.096 & 0.029 & 0.073 & 0.070 & -1.347 & -0.012 \\
\hline & $(0.106)$ & $(0.737)$ & $(0.367)$ & $(0.208)$ & $(0.230)$ & $(0.417)$ \\
\hline & $(0.078)$ & $(0.376)$ & $(0.316)$ & $(0.118)$ & $(0.246)$ & $(0.327)$ \\
\hline \multirow{2}{*}{ TECHNOLOGY } & $0.161^{* *}$ & 0.073 & 0.125 & $0.106^{*}$ & -1.406 & 0.002 \\
\hline & $(0.012)$ & $(0.385)$ & $(0.123)$ & $(0.071)$ & $(0.236)$ & $(0.899)$ \\
\hline Arellano-Bond test $\operatorname{AR}(1)(z, p>|z|)$ & $-3.90(0.000)$ & $-4.63(0.000)$ & $-4.20(0.000)$ & $-4.32(0.000)$ & $-3.67(0.000)$ & $-4.61(0.000)$ \\
\hline Arellano-Bond test $\mathbf{A R}(2)(\mathrm{z}, \mathrm{p}>|\mathrm{z}|)$ & $0.46(0.646)$ & $0.24(0.811)$ & $0.49(0.627)$ & $0.42(0.676)$ & $0.11(0.916)$ & $-0.68(0.494)$ \\
\hline Hansen test (Chi-square, $\mathbf{p}>\left|\mathbf{C h i}^{2}\right|$ ) & $65.53(0.748)$ & $35.95(0.830)$ & $38.80(0.731)$ & $51.76(0.561)$ & $43.95(0.779)$ & $44.04(0.512)$ \\
\hline
\end{tabular}

RD_INTENSITY is the ratio between Research and Development expenses and the total sales; POW_DIST represents the power distance, one of the six culture dimensions addressed by Hostfede (2010) and ranges from 0 to 100; INDIV represents the individualism, one of the six culture dimensions addressed by Hostfede (2010) and ranges from 0 to 100; MASCUL represents the masculinity, one of the six culture dimensions addressed by Hostfede (2010) and ranges from 0 to 100; UNC_AVOID represents the uncertainity avoidance, one of the six culture dimensions addressed by Hostfede (2010) and ranges from 0 to 100; LONG_ORIENTATION represents the long-term orientation, one of the six culture dimensions addressed by Hostfede (2010) and ranges from 0 to 100; INDULG represents the indulgence, one of the six culture dimensions addressed by Hostfede (2010) and ranges from 0 to 100; SIZE is the log of total assets; ROA is the operate income before interests and taxes over total assets; LEVERAGE is the debt over total assets; B_SIZE is the number of directors on board; B INDEP is the proportion of independent directors on boards= Total number of independent on boards/ Total number of directors on boards; GOVERN is the ratio between the addition of 4 components, which range from 0 to 10, and the total number of components (4). The four components are (a) government consumption, (b) transfers and subsidies, (c) government enterprises and investment and (d) top marginal tax rate. Governance indicates the extent to which countries rely on the political process to allocate resources and goods and services; LIQUIDITY is the ratio between total current assets and total current liabilities; GDP is the log of gross domestic product of the country; BASIC MATERIALS is a dummy variable: $1=$ Basic Materials; $0=$ Otherwise; CONSUMER NON-CYCLICAL is a dummy variable: $1=$ Consumer Non-Cyclical; $0=$ Otherwise; ENERGY is a dummy variable: $1=$ Energy; $0=$ Otherwise; ; INDUSTRIALS is a dummy variable: $1=$ Industrial; $0=$ Otherwise; UTILITIES is a dummy variable: $1=$ Utilities; $0=$ Otherwise; CONSUMER CYCLICAL is a dummy variable: $1=$ Consumer Cyclical; $0=$ Otherwise; HEALTHCARE is a dummy variable: $1=$ Healthcare; $0=$ Otherwise; TECHNOLOGY is a dummy variable: $1=$ Technology; $0=$ Otherwise and TELECOMMUNICATION SERVICES is a dummy variable: $1=$ Telecommunication Services; $0=$ Otherwise. ${ }^{*}$ p-value $<0.1 * *$ p-value $<0.05 * * *$ p-value $<0.01$. 